University of Nebraska - Lincoln

DigitalCommons@University of Nebraska - Lincoln

\title{
Fiber Digestion Dynamics of Sward Components within Switchgrass Populations
}

\author{
Daren D. Redfearn \\ Louisiana State University, dredfearn2@unl.edu \\ Kenneth J. Moore \\ lowa State University \\ Kenneth P. Vogel \\ University of Nebraska-Lincoln, kvogel1@unl.edu \\ Steven S. Waller \\ University of Nebraska-Lincoln, swaller1@unl.edu \\ Robert B. Mitchell \\ Texas Tech University, rob.mitchell@ars.usda.gov
}

Follow this and additional works at: https://digitalcommons.unl.edu/usdaarsfacpub

Redfearn, Daren D.; Moore, Kenneth J.; Vogel, Kenneth P.; Waller, Steven S.; and Mitchell, Robert B., "Fiber Digestion Dynamics of Sward Components within Switchgrass Populations" (1999). Publications from USDA-ARS / UNL Faculty. 1917.

https://digitalcommons.unl.edu/usdaarsfacpub/1917

This Article is brought to you for free and open access by the U.S. Department of Agriculture: Agricultural Research Service, Lincoln, Nebraska at DigitalCommons@University of Nebraska - Lincoln. It has been accepted for inclusion in Publications from USDA-ARS / UNL Faculty by an authorized administrator of DigitalCommons@University of Nebraska - Lincoln. 


\title{
CROP QUALITY \& UTILIZATION
}

\section{Fiber Digestion Dynamics of Sward Components within Switchgrass Populations}

\author{
Daren D. Redfearn,* Kenneth J. Moore, Kenneth P. Vogel, Steven S. Waller, and Robert B. Mitchell
}

\begin{abstract}
Forage quality as it relates to plant maturity is well established; however, strategies for improving fiber digestion in switchgrass populations have not been determined. The objectives of this study were to determine fiber digestion of sward components within switchgrass (Panicum virgatum $\mathbf{L}_{\text {.) }}$ ) populations and which aspects of fiber digestion dynamics caused in vitro dry matter disappearance (IVDMD) differences of six switchgrass populations. This study was conducted in 1993 near Ames, IA, and Mead, NE. The experimental design was a randomized complete block design with a split-plot arrangement of treatments with four replicates at each location. Whole plots were populations and subplots were sward maturity. 'Trailblazer', 'Pathfinder', 'Cave-in-Rock', and three experimental switchgrass populations were used in this study. Populations were harvested on 9 June, 19 July, and 27 August at Ames and on 10 June, 27 July, and 26 August at Mead. Fiber composition and digestibility were determined on leaf blade, leaf sheath, and stem fractions of the primary growth stages. Significant differences for theoretical true digestibility (TD) and neutral detergent fiber (NDF) existed for morphological components at each sward maturity. However, digestion characteristics of the sward components were not stable across primary growth stages. Rate of fiber digestion was faster for most sward components at Ames than Mead, although stems of elongating tillers from elongating swards digested faster on plants grown at Mead than Ames. Rate of fiber digestion of stems was typically slower than either leaf blades or sheaths, but in several instances they were similar or stems had faster rates of fiber digestion. Although phenotypic selection can increase fiber digestibility, plant maturity remains an important factor, and selections may require evaluation at different stages of morphological development. Thus, improvements in forage digestion, at least in switchgrass, may only be manifested for the growth stage at which it was selected.
\end{abstract}

Im MPROVED ruminant animal production can be achieved by selectively breeding forages for increased IVDMD. Vogel et al. (1981) showed that it was possible to select switchgrass for increased and decreased

D.D. Redfearn, Louisiana State Univ. Agric. Center, Southeast Res. Stn., Franklinton, LA 70438; K.J. Moore, Dep. of Agronomy, lowa State Univ., Ames, IA 50011; K.P. Vogel, USDA-ARS and Dep. of Agronomy, Univ. of Nebraska and S.S. Waller, Dep. of Agronomy, Univ. of Nebraska, Lincoln, NE 68583; and R.B. Mitchell, Dep. of Range, Wildlife, and Fisheries Manage., Texas Tech Univ., Lubbock, TX 79416. The research reported in this article is from a dissertation submitted by the senior author in partial fulfillment of the requirements for a Ph.D. from the Univ. of Nebraska. The research was funded in part by the U.S. Dep. of Energy Biomass Fuels program, Oak Ridge Natl. Lab. Contract no. DE-A105-900R21954. Joint contribution from the Nebraska Agric. Exp. Stn. and Iowa Agric. and Home Econ. Exp. Stn. Published as Journal Series no. 12150, Nebraska Agric. Exp. Stn. Mention of a trade name does not constitute a guarantee of the product by the USDA or the Univ. of Nebraska and does not imply its approval to the exclusion of other suitable products. Received 5 June 1998. *Corresponding author (dredfearn@agctr.lsu.edu)

Published in Crop Sci. 39:784-789 (1999).
IVDMD from the same base population. In a subsequent 3-yr grazing evaluation, the population selected for increased IVDMD resulted in a $24 \%$ improvement in average daily gain and additional seasonal gains of $311 \mathrm{~kg}$ beef ha $\mathrm{a}^{-1}$ (Anderson et al., 1988). The highIVDMD selection was released as Trailblazer (Vogel et al., 1991), which is similar in maturity to Pathfinder, but with increased IVDMD.

Digestible forage fractions for ruminants can be divided into cell solubles $\left(C_{S}\right)$ and digestible fiber $\left(C_{D}\right)$ components. The $\mathrm{C}_{\mathrm{S}}$ fraction is assumed to be completely available to rumen microbes as readily available sources of fermentable energy (Van Soest, 1982), whereas digestibility of $C_{D}$ is partial and more variable. Forage fiber contains a potentially digestible fraction, which disappears from the rumen via digestion and passage, and an indigestible fraction which is removed from the rumen by passage only (Waldo and Smith, 1972; Allen and Mertens, 1988). Extent of forage digestion is therefore limited by microbial access to fiber constituents, which in turn depends upon digestion lag time, rate of digestion, and rumen residence time. Forage fiber digestibility can thus be expressed as a function of its chemical constituents and their associated digestion coefficients (Moore and Cherney, 1986).

Although the changes in forage quality that occur with plant maturity are clearly defined (Nelson and Moser, 1994), factors that influence forage quality of switchgrass sward components through changes in tiller maturation have not been adequately determined. Twidwell et al. (1988) investigated maturity effects in Trailblazer, Pathfinder, and Cave-in-Rock switchgrass harvested when the flag leaf became visible and twice more at 14-d intervals. They found that forage quality and rate of fiber digestion declined primarily as a result of increased stem proportion. Plant maturity and genetic composition appear to be the principle factors influencing forage quality within these switchgrass populations (Hopkins et al., 1995; Vogel et al., 1981).

Phenotypic selection for overall forage quality improvement involves selecting for the interacting effects of tiller morphogenesis and digestion dynamics of sward components. Evaluating the digestion dynamics of switchgrass populations subjected to previous phenotypic selection for improved forage quality leads to better understanding of strategies for improving this forage. Objectives of this study were to determine (i) the influence of sward and tiller maturity on fiber digestion of the

Abbreviations: $\mathrm{C}_{\mathrm{S}}$, cell solubles; $\mathrm{C}_{\mathrm{D}}$, digestible fiber; $\mathrm{DM}$, dry matter; NDF, neutral detergent fiber; $\mathrm{G} \times \mathrm{E}$, genotype $\times$ environment; IVDMD, in vitro dry matter disappearance; NIRS, near-infrared reflectance spectroscopy; TD, true digestibility. 
leaf blades, leaf sheaths, and stems of six switchgrass populations and (ii) relationships between fiber digestion and known IVDMD differences of six switchgrass populations.

\section{MATERIALS AND METHODS}

This study was conducted during 1993 at the University of Nebraska Agricultural Research and Development Center near Mead, NE, on a Sharpsburg silty clay loam (fine, montmorillonitic, mesic, Typic Argiudoll) and at the Iowa State University Agronomy and Agricultural Engineering Research Center near Ames, IA, on a Webster silty clay loam (fineloamy, mixed, mesic, Typic Endoaquolls). The experimental plots used in the current study were switchgrass yield-trial plots that were established to evaluate genotype and genotype $\times$ environment $(G \times E)$ interactions in switchgrass (Hopkins et al., 1995). Plots were established in the spring of 1990 as a randomized complete block design with four replicates of 20 switchgrass cultivars and experimental strains at each location. Plot size at Ames was 3.7 by $0.9 \mathrm{~m}$ and plot size at Mead was 4.5 by $1.5 \mathrm{~m}$. Each plot was divided into three subplots to be harvested randomly at three different harvest dates.

This study used three commercially available switchgrass cultivars (Trailblazer, Pathfinder, and Cave-in-Rock) and three experimental populations selected for either high or low IVDMD or DM yield. These populations were developed by the USDA-ARS forage grass breeding project located at Lincoln, NE. Descriptions of genetic backgrounds of the switchgrass populations follow the nomenclature previously used by Vogel et al. (1991) and Hopkins et al. (1993). Trailblazer was developed by one cycle of selection for high IVDMD in the Ey $\times$ FF population which originated from selections made in Nebraska and Kansas and is similar in maturity and adaptation to Pathfinder, but with greater IVDMD (Vogel et al., 1991). Pathfinder is a synthetic cultivar developed from selections made in Nebraska and Kansas (Newell, 1968), and Cave-in-Rock was developed from selections made in southern Illinois and developed by the USDA Natural Resources Conservation Service Plant Materials Center at Ellsberry, MO. The three experimental populations were Ey $\times$ FF Low IVDMD Cycle 1, Ey $\times$ FF High IVDMD Cycle 3, and Pathfinder High Yield-DMD Cycle 2. The Ey $\times$ FF Low IVDMD Cycle 1 population was the same population described by Vogel et al. (1991) for decreased IVDMD. The Ey $\times$ FF High IVDMD Cycle 3 population was selected from the same base population as Trailblazer for three cycles of selection for increased IVDMD (Hopkins et al., 1993). Pathfinder High Yield-DMD Cycle 2 was selected from Pathfinder using two cycles of recurrent restricted phenotypic selection for both increased DM yield and IVDMD.

The previous year's growth was removed in the fall after a killing frost. All plots received $122 \mathrm{~kg} \mathrm{ha}^{-1} \mathrm{~N}$ in the form of $\mathrm{NH}_{4} \mathrm{NO}_{3}$ approximately $1 \mathrm{wk}$ following initiation of spring growth. Samples were collected on 9 June (vegetative), 19 July (elongating), and 27 August (reproductive) at Ames and on 10 June (vegetative), 27 July (elongating), and 26 August (reproductive) at Mead. These dates were chosen to approximate tiller populations in the mid-vegetative, mid-elongating, and mid-reproductive stages of development on the basis of the relationship of switchgrass morphological development to day of the year (Mitchell et al., 1997). The nature of this study precluded the separation of maturity effects with forage quality effects because we harvested all plots at each location on the same day. The alternative would have been to harvest each population at the same stage of growth. This, however, would have confounded days of growth with forage quality.
Maturity differences for these populations have been previously reported (Redfearn et al., 1997).

Samples were harvested by hand-clipping all tillers at ground level from a randomly placed $0.1-\mathrm{m}^{2}$ quadrat within each subplot. Harvested tillers were separated by primary growth stage according to Moore et al. (1991) and dried in a forced-draft oven at $55^{\circ} \mathrm{C}$. Tillers were separated into leaf blade, leaf sheath, and stem (stem + inflorescence) components and combined according to primary growth stage. Further discussion of primary stage descriptions follow the definitions given by Moore et al. (1991).

Samples were ground in a shear mill to pass a $2-\mathrm{mm}$ screen and reground in a cyclone mill to pass a $1-\mathrm{mm}$ screen to achieve a uniform particle size to facilitate collection of sample spectra by near-infrared reflectance spectroscopy (NIRS). Sample spectra were collected for leaf blades, leaf sheaths, and stem fractions pooled according to primary growth stage by harvest date with a Model 6500 scanning monochromator (NIRSystems, Silver Springs, MD). A subset of 72 component samples was selected for equation development. Modified partial least squares and partial least squares regression were used to develop prediction equations for neutral detergent fiber (NDF) and NDF residues (Table 1). Fewer than 72 samples were used for several of the prediction equations because some samples were considered outliers by the regression procedures.

Leaf blade, leaf sheath, and stem samples were analyzed for NDF concentrations by the procedures of Goering and Van Soest (1970), which were modified by excluding decalin and sodium sulfite (Robertson and Van Soest, 1977). Fiber digestion parameters were determined by in vitro incubation periods with time points ending at 18,36 , and $72 \mathrm{~h}$ by the inoculation procedures described by Marten and Barnes (1980). Samples were hydrated for $16 \mathrm{~h}$ prior to inoculation. Rumen fluid was collected from two steers (Bos taurus), one fed alfalfa (Medicago sativa L.) and the other fed ground corn (Zea mays L.) cobs, and these fluids were blended together $(1: 1 \mathrm{v} / \mathrm{v})$. This inoculum was used because previous studies investigating these switchgrass populations also used this inoculum (Hopkins et al., 1995; Moore et al., 1993; Vogel et al., 1981). The undigested residues were refluxed for $1 \mathrm{~h}$ in neutral detergent solution (Goering and Van Soest, 1970) and filtered to remove the soluble fraction. These residues were used to estimate TD according to Moore et al. (1993) and partitioned into $C_{S}, C_{D}$, and their associated digestion parameters:

$$
\begin{aligned}
\mathrm{TD} & =C_{\mathrm{S}}+C_{\mathrm{D}}\left[1-\mathrm{e}^{-\mathrm{k}(\mathrm{t}-\mathrm{L})}\right] \\
C_{\mathrm{S}} & =1000-\mathrm{NDF}=1000-C_{0} \\
C_{\mathrm{D}} & =\text { initial NDF }-(\text { residual NDF at } 72 \mathrm{~h}) \\
& =C_{0}-C_{72}
\end{aligned}
$$

where

$$
\begin{aligned}
C_{0}= & \mathrm{NDF} \text { concentration }\left(\mathrm{g} \mathrm{NDF} \mathrm{kg}^{-1}\right. \text { initial DM) and } \\
C_{72}= & \text { residual NDF concentration }\left(\mathrm{g} \mathrm{NDF} \mathrm{kg} \mathrm{g}^{-1}\right. \text { initial DM) } \\
& \text { following } 72 \mathrm{~h} \text { in vitro incubation. }
\end{aligned}
$$

Extent of fiber digestion was calculated as

$$
\left(C_{0}-C_{72}\right) / C_{0}
$$

Rate of fiber digestion $(k)$ and digestion lag time $(L)$ were then calculated by

$$
\begin{aligned}
k= & {\left[\ln \left(C_{18}-C_{72}\right)-\ln \left(C_{36}-C_{72}\right)\right] /[18-36] } \\
L= & -\left\{\left(\ln C_{0}-C_{72}\right)-0.5\left[\ln \left(C_{18}-C_{72}\right)\left(C_{36}-C_{72}\right)\right.\right. \\
& -k(18+36)]\} / k
\end{aligned}
$$


Table 1. Near-infrared reflectance spectroscopy calibration statistics for vegetative, elongating, and reproductive leaf blades, leaf sheaths, and stems from six switchgrass populations grown at Ames, IA, and Mead, NE, during 1993.

\begin{tabular}{|c|c|c|c|c|c|}
\hline Variable & $\begin{array}{c}\text { Number } \\
\text { of samples }\end{array}$ & $\begin{array}{l}\text { Standard error } \\
\text { of calibration }\end{array}$ & $\boldsymbol{R}^{2}$ & $\begin{array}{l}\text { Standard error of } \\
\text { cross validation }\end{array}$ & 1-VR† \\
\hline Neutral detergent fiber & 71 & 13.8 & 0.97 & 18.4 & 0.94 \\
\hline Residual NDF following $18 \mathrm{~h}$ in vitro fermentation & 72 & 25.7 & 0.92 & 36.8 & 0.92 \\
\hline Residual NDF following $36 \mathrm{~h}$ in vitro fermentation & 71 & 25.6 & 0.95 & 36.4 & 0.95 \\
\hline Residual NDF following $72 \mathrm{~h}$ in vitro fermentation & $\mathbf{7 0}$ & 28.9 & 0.97 & 37.6 & 0.95 \\
\hline
\end{tabular}

$\dagger$ Proportional variation in the reference method values predicted by NIRS.

where

$$
C_{18}=\begin{aligned}
\text { Residual NDF concentration }\left(\mathrm{g} \mathrm{NDF} \mathrm{kg}^{-1}\right. \\
\text { initial DM) following } 18 \mathrm{~h} \text { in vitro incubation }
\end{aligned}
$$

and

$$
\begin{aligned}
C_{36}= & \text { Residual NDF concentration ( } \mathrm{g} \text { NDF kg-1 } \\
& \text { initial DM) following } 36 \mathrm{~h} \text { in vitro incubation. }
\end{aligned}
$$

The experiment was designed as a randomized complete block with a split-plot arrangement of treatment combinations. Whole plots were populations and subplots were sward maturities. Locations and blocks nested within location were assumed to be random factors with populations and sward maturities considered fixed (McIntosh, 1983). Data were analyzed by the General Linear Model (GLM) procedures of SAS (1985). All tests of significance were made at the 0.05 level of probability unless otherwise noted.

\section{RESULTS}

\section{Digestion Parameters}

Differences in TD, NDF, and extent of fiber digestion existed in switchgrass leaf blades and leaf sheaths from vegetative (June harvest) swards (Table 2). Averaged across populations, forage quality, when different, was greater at Ames than Mead. Because internode elongation had not begun in any of these switchgrass populations, vegetative swards contained only leaf blades and leaf sheaths. Averaged across all populations, TD was 872 and $845 \mathrm{~g} \mathrm{~kg}^{-1}$ for leaf blades and leaf sheaths, respectively. For both components, Ey $\times$ FF High IVDMD Cycle 3 and Pathfinder High Yield-DMD Cycle 2 had TD greater than the other switchgrass populations. This occurred in spite of Cave-in-Rock having

Table 2. Means for true digestibility, neutral detergent fiber, and

\begin{tabular}{|c|c|c|c|c|c|c|}
\hline \multirow{2}{*}{$\begin{array}{l}\text { Location, } \\
\text { across populations }\end{array}$} & \multicolumn{2}{|c|}{$\begin{array}{c}\text { True } \\
\text { digestibility }\end{array}$} & \multicolumn{2}{|c|}{$\begin{array}{c}\text { Neutral } \\
\text { detergent } \\
\text { fiber }\end{array}$} & \multicolumn{2}{|c|}{$\begin{array}{c}\begin{array}{c}\text { Extent of } \\
\text { fiber digestion }\end{array} \\
\end{array}$} \\
\hline & Blade & Sheath & Blade & Sheath & Blade & Sheath \\
\hline & & & $-\mathbf{g}$ & $n^{-1}$ & & \\
\hline $\begin{array}{l}\text { Ames } \\
\text { Mead } \\
\text { LSD }(0.05)\end{array}$ & $\begin{array}{r}880 \\
864 \\
8\end{array}$ & $\begin{array}{r}866 \\
823 \\
7\end{array}$ & $\begin{array}{l}586 \\
593 \\
\text { NS }\end{array}$ & $\begin{array}{r}591 \\
613 \\
8\end{array}$ & $\begin{array}{r}795 \\
772 \\
11\end{array}$ & $\begin{array}{r}774 \\
713 \\
10\end{array}$ \\
\hline \multicolumn{7}{|c|}{ Population, across locations } \\
\hline $\begin{array}{l}\text { Trailblazer } \\
\text { Pathfinder } \\
\text { Cave-in-Rock } \\
\text { Ey } \times \text { FF LDMDC1 } \\
\text { Ey } \times \text { FF HDMDC3 } \\
\text { Pathfinder HYDMDC2 } \\
\text { LSD (0.05) }\end{array}$ & $\begin{array}{r}869 \\
865 \\
861 \\
856 \\
896 \\
885 \\
14\end{array}$ & \begin{tabular}{r|}
836 \\
842 \\
856 \\
812 \\
855 \\
868 \\
13
\end{tabular} & $\begin{array}{r}595 \\
602 \\
559 \\
605 \\
581 \\
597 \\
21\end{array}$ & $\begin{array}{r}605 \\
612 \\
584 \\
621 \\
597 \\
601 \\
14\end{array}$ & $\begin{array}{r}780 \\
776 \\
751 \\
762 \\
822 \\
807 \\
20\end{array}$ & $\begin{array}{r}\mathbf{7 3 0} \\
\mathbf{7 4 2} \\
\mathbf{7 5 4} \\
\mathbf{6 9 7} \\
\mathbf{7 5 8} \\
\mathbf{7 8 0} \\
\mathbf{1 7}\end{array}$ \\
\hline
\end{tabular}
72-h extent of fiber digestion of leaf blades and leaf sheaths from vegetative swards of six switchgrass populations grown at Ames, IA, and Mead, NE, during 1993. lower leaf blade and leaf sheath NDF concentrations than either Ey $\times$ FF High IVDMD Cycle 3 and Pathfinder High Yield-DMD Cycle 2. Trailblazer, Pathfinder, and Ey $\times$ FF Low IVDMD Cycle 1 were similar to Cave-in-Rock for TD, NDF, and extent of fiber digestion (Table 2).

The elongating (July harvest) sward maturity in this study corresponded to the vegetative sward maturity described by Hopkins et al. (1995), who observed significant differences for IVDMD in these same switchgrass populations. Elongating swards included leaf blades, leaf sheaths, and stems from both elongating and reproductive tillers. The stem fraction had a minimal impact on overall forage digestion because the stem from elongating and reproductive tillers in elongating swards had not fully elongated, except for Cave-in-Rock at Mead (Redfearn et al., 1997). Averaged across populations, forage quality of the sward components from elongating swards was generally greater at Ames than Mead (Tables 3 and 4). Although leaf blade and leaf sheath TD from elongating tillers and leaf sheaths from reproductive tillers did not differ by population, differences in TD were observed for stems from elongating tillers and leaf blades and stems from reproductive tillers (Table 3 ). Stems from elongating tillers of Trailblazer, Ey $\times$ FF High IVDMD Cycle 3, and Cave-in-Rock had significantly greater TD than Pathfinder High Yield-DMD Cycle 2, Ey $\times$ FF Low IVDMD Cycle 1, and Pathfinder (Table 3). Leaf blades of reproductive tillers in Pathfinder, Cave-in-Rock, Ey $\times$ FF Low IVDMD Cycle 1, and Ey $\times$ FF High IVDMD Cycle 3 had significantly greater TD than Trailblazer and Pathfinder High YieldDMD Cycle 2.

Responses of NDF of morphological components in elongating swards were not as straightforward as with TD. Generally, Cave-in-Rock had among the lowest NDF concentrations for all morphological components in both elongating and reproductive growth stages of elongating swards (Table 4). Conversely, Pathfinder had among the greater NDF concentrations for the leaf sheath and stem components, but among the lowest NDF concentrations for leaf blades in both primary growth stages of elongating swards (Table 4). Although significant differences were apparent for NDF concentration in leaf sheaths of elongating and reproductive tillers, these differences were less than $30 \mathrm{~g} \mathrm{~kg}^{-1}$ and deemed nutritionally unimportant.

In contrast to elongating swards, reproductive swards (August harvest) had significant TD differences for leaf blades, leaf sheaths, and stems of all populations (Table 3 ). Trailblazer had consistently greater TD for leaf 
Table 3. True digestibility of leaf blade, leaf sheath, and stem components of elongating and reproductive tillers within elongating and reproductive swards of six switchgrass populations from Ames, IA, and Mead, NE, harvested during 1993.

\begin{tabular}{|c|c|c|c|c|c|c|c|c|c|c|c|c|}
\hline \multirow[b]{3}{*}{ Location, across population } & \multicolumn{6}{|c|}{ July harvest } & \multicolumn{6}{|c|}{ August harvest } \\
\hline & \multicolumn{3}{|c|}{ Elongating } & \multicolumn{3}{|c|}{ Reproductive } & \multicolumn{3}{|c|}{ Elongating } & \multicolumn{3}{|c|}{ Reproductive } \\
\hline & Blade & Sheath & Stem & Blade & Sheath & Stem & Blade & Sheath & Stem & Blade & Sheath & Stem \\
\hline $\begin{array}{l}\text { Ames } \\
\text { Mead } \\
\text { LSD (0.05) }\end{array}$ & $\begin{array}{r}719 \\
694 \\
8\end{array}$ & $\begin{array}{r}680 \\
630 \\
25\end{array}$ & $\begin{array}{l}\mathbf{5 4 6} \\
\mathbf{5 2 7} \\
\text { NS }\end{array}$ & $\begin{array}{l}691 \\
696 \\
\text { NS }\end{array}$ & $\begin{array}{l}663 \\
648 \\
\text { NS }\end{array}$ & $\begin{array}{r}523 \\
439 \\
27\end{array}$ & $\begin{array}{r}613 \\
580 \\
8\end{array}$ & $\begin{array}{r}532 \\
569 \\
11\end{array}$ & $\begin{array}{r}400 \\
441 \\
15\end{array}$ & $\begin{array}{r}653 \\
575 \\
14\end{array}$ & $\begin{array}{r}530 \\
568 \\
10\end{array}$ & $\begin{array}{l}362 \\
366 \\
\text { NS }\end{array}$ \\
\hline \multicolumn{13}{|l|}{ Population, across location } \\
\hline $\begin{array}{l}\text { Trailblazer } \\
\text { Pathfinder } \\
\text { Cave-in-Rock } \\
\text { Ey } \times \text { FFLDMDC1 } \\
\text { Ey } \times \text { FFHDMDC3 } \\
\text { Pathfinder HYDMDC2 } \\
\text { LSD (0.05) }\end{array}$ & $\begin{array}{l}06 \\
707 \\
711 \\
688 \\
718 \\
709 \\
\text { NS }\end{array}$ & $\begin{array}{l}652 \\
653 \\
667 \\
646 \\
643 \\
675 \\
\text { NS }\end{array}$ & $\begin{array}{r}\mathbf{5 6 0} \\
\mathbf{5 0 7} \\
\mathbf{5 4 6} \\
\mathbf{5 2 1} \\
\mathbf{5 5 9} \\
\mathbf{5 2 6} \\
\mathbf{2 6}\end{array}$ & $\begin{array}{r}640 \\
710 \\
698 \\
693 \\
721 \\
698 \\
15\end{array}$ & $\begin{array}{l}661 \\
644 \\
649 \\
635 \\
675 \\
670 \\
\text { NS }\end{array}$ & $\begin{array}{l}521 \\
445 \\
468 \\
459 \\
489 \\
504 \\
\text { NS }\end{array}$ & $\begin{array}{r}647 \\
564 \\
606 \\
595 \\
572 \\
595 \\
14\end{array}$ & $\begin{array}{l}\mathbf{5 5 1} \\
\mathbf{5 3 7} \\
\mathbf{5 5 9} \\
\mathbf{5 3 7} \\
\mathbf{5 7 1} \\
\mathbf{5 4 9} \\
\mathbf{N S}\end{array}$ & $\begin{array}{r}413 \\
417 \\
413 \\
388 \\
474 \\
417 \\
27\end{array}$ & $\begin{array}{r}639 \\
627 \\
649 \\
579 \\
583 \\
606 \\
\mathbf{2 4}\end{array}$ & $\begin{array}{r}\mathbf{5 6 1} \\
\mathbf{5 2 2} \\
\mathbf{5 5 2} \\
\mathbf{5 2 9} \\
\mathbf{5 7 6} \\
\mathbf{5 5 4} \\
\mathbf{1 8}\end{array}$ & $\begin{array}{r}365 \\
348 \\
366 \\
338 \\
402 \\
402 \\
366 \\
20\end{array}$ \\
\hline
\end{tabular}

blades and leaf sheaths of both elongating and reproductive tillers in the reproductive swards, although stems from elongating tillers of Trailblazer had among the lowest TD concentrations (Table 3 ). The Ey $\times$ FF High IVDMD Cycle 3 population had TD in leaf blades from elongating and reproductive tillers similar to those of Trailblazer; however, stem TD for both elongating and reproductive tillers were greater than those of Trailblazer (Table 3 ). Conversely, the Ey $\times$ FF Low IVDMD Cycle 1 population had consistently low TD for morphological components of both elongating and reproductive primary growth stages. Leaf blade NDF from reproductive tillers did not significantly differ among populations. Averaged across locations, forage quality for sward components of reproductive swards was generally greater at Ames than Mead (Tables 3 and 4). The location differences for vegetative, elongating, and reproductive swards may be partially due to less mature swards at Ames than Mead (Redfearn et al., 1997).

\section{In Vitro Digestion Kinetics}

Rate of fiber digestion for leaf blades, leaf sheaths, and stems in vegetative swards differed more by location than by population (Table 5). Averaged across populations, rates of fiber digestion were faster for both blade and sheath components in vegetative swards at Ames than at Mead. Cave-in-Rock had the fastest rate of fiber digestion for leaf blades and sheaths, but rate constants for leaf blades and sheaths of the other populations were not different (Table 5). Elongating swards were predominately elongating tillers, although numerous reproductive tillers were present (Redfearn et al., 1997). Similarly to vegetative swards, rate of fiber digestion of elongating swards differed by both location and population, although the differences were small (Table 5). Population $\times$ location interactions occurred for rate of fiber digestion for leaf blades in reproductive tillers. The major reason for the significant interaction was the reversed ranking for rate of fiber digestion for the $E y \times$ FF High IVDMD Cycle 3 population. Leaf blades of this population had the slowest rate of fiber digestion at Ames $\left(0.034 \mathrm{~h}^{-1}\right)$, but the fastest rate of digestion at Mead $\left(0.054 \mathrm{~h}^{-1}\right)$. Generally, rate of fiber digestion was more rapid at Ames than Mead (Table 5). These rate constants were similar to others reported from similar switchgrass populations (Twidwell et al., 1988; Fritz et al., 1991).

\section{DISCUSSION}

Because differences in NDF for leaf blades and leaf sheaths were normally small, the observed differences in TD most likely resulted from increased $C_{D}$ because of a greater extent of fiber digestion (Table 6). The high

Table 4. Neutral detergent fiber of leaf blade, leaf sheath, and stem components of elongating and reproductive tillers within elongating and reproductive swards of six switchgrass populations from Ames, IA, and Mead, NE, harvested during 1993.

\begin{tabular}{|c|c|c|c|c|c|c|c|c|c|c|c|c|}
\hline \multirow[b]{3}{*}{ Location, across population } & \multicolumn{6}{|c|}{ July harvest } & \multicolumn{6}{|c|}{ August harvest } \\
\hline & \multicolumn{3}{|c|}{ Elongating } & \multicolumn{3}{|c|}{ Reproductive } & \multicolumn{3}{|c|}{ Elongating } & \multicolumn{3}{|c|}{ Reproductive } \\
\hline & Blade & Sheath & Stem & Blade & Sheath & Stem & Blade & Sheath & Stem & Blade & Sheath & Stem \\
\hline $\begin{array}{l}\text { Ames } \\
\text { Mead } \\
\text { LSD (0.05) }\end{array}$ & $\begin{array}{r}643 \\
676 \\
5\end{array}$ & $\begin{array}{r}698 \\
716 \\
10\end{array}$ & $\begin{array}{r}766 \\
748 \\
8\end{array}$ & $\begin{array}{r}657 \\
678 \\
6\end{array}$ & $\begin{array}{r}706 \\
727 \\
6\end{array}$ & $\begin{array}{l}772 \\
781 \\
\text { NS }\end{array}$ & $\begin{array}{l}653 \\
650 \\
\text { NS }\end{array}$ & $\begin{array}{r}745 \\
728 \\
6\end{array}$ & $\begin{array}{l}774 \\
765 \\
\text { NS }\end{array}$ & $\begin{array}{r}652 \\
640 \\
6\end{array}$ & $\begin{array}{r}754 \\
740 \\
6\end{array}$ & $\begin{array}{l}795 \\
791 \\
\text { NS }\end{array}$ \\
\hline \multicolumn{13}{|l|}{ Population, across location } \\
\hline $\begin{array}{l}\text { Trailblazer } \\
\text { Pathfinder } \\
\text { Cave-in-Rock } \\
\text { Ey } \times \text { FFLDMDC1 } \\
\text { Ey } \times \text { FFHDMDC3 } \\
\text { Path finder HYDMDC2 } \\
\text { LSD }(0.05)\end{array}$ & $\begin{array}{r}667 \\
654 \\
639 \\
667 \\
663 \\
667 \\
11\end{array}$ & $\begin{array}{l}708 \\
712 \\
693 \\
712 \\
710 \\
707 \\
\text { NS }\end{array}$ & $\begin{array}{r}\mathbf{7 5 2} \\
\mathbf{7 7 1} \\
\mathbf{7 3 8} \\
\mathbf{7 5 8} \\
\mathbf{7 5 1} \\
\mathbf{7 7 3} \\
\mathbf{1 3}\end{array}$ & $\begin{array}{r}\mathbf{6 7 6} \\
\mathbf{6 5 9} \\
\mathbf{6 5 5} \\
\mathbf{6 7 3} \\
\mathbf{6 5 9} \\
\mathbf{6 8 3} \\
\mathbf{1 0}\end{array}$ & $\begin{array}{r}\mathbf{7 1 6} \\
\mathbf{7 2 8} \\
\mathbf{7 0 4} \\
\mathbf{7 2 9} \\
\mathbf{7 0 1} \\
\mathbf{7 1 9} \\
\mathbf{1 0}\end{array}$ & $\begin{array}{l}768 \\
799 \\
769 \\
788 \\
763 \\
773 \\
\text { NS }\end{array}$ & $\begin{array}{l}654 \\
659 \\
655 \\
644 \\
649 \\
646 \\
\text { NS }\end{array}$ & $\begin{array}{r}\mathbf{7 4 0} \\
\mathbf{7 5 0} \\
\mathbf{7 2 3} \\
\mathbf{7 3 7} \\
\mathbf{7 3 0} \\
\mathbf{7 3 9} \\
\mathbf{1 1}\end{array}$ & $\begin{array}{r}\mathbf{7 7 7} \\
\mathbf{7 7 7} \\
\mathbf{7 5 0} \\
\mathbf{7 7 8} \\
\mathbf{7 5 8} \\
\mathbf{7 7 7} \\
\mathbf{1 3}\end{array}$ & $\begin{array}{l}649 \\
652 \\
644 \\
644 \\
643 \\
644 \\
\text { NS }\end{array}$ & $\begin{array}{r}\mathbf{7 5 1} \\
\mathbf{7 5 8} \\
\mathbf{7 2 7} \\
\mathbf{7 5 0} \\
\mathbf{7 4 6} \\
\mathbf{7 5 2} \\
\mathbf{1 0}\end{array}$ & $\begin{array}{r}802 \\
803 \\
757 \\
801 \\
799 \\
795 \\
71 \\
11\end{array}$ \\
\hline
\end{tabular}


Table 5. Digestion coefficients of leaf blade, leaf sheath, and stem components of vegetative tillers within a vegetative sward maturity and elongating and reproductive tillers within elongating and reproductive swards of six switchgrass populations from Ames, IA, and Mead, NE, during 1993.

\begin{tabular}{|c|c|c|c|c|c|c|c|c|c|c|c|c|c|c|}
\hline \multirow[b]{3}{*}{ Location, across population } & \multirow{2}{*}{\multicolumn{2}{|c|}{$\frac{\text { June harvest }}{\text { Vegetative }}$}} & \multicolumn{6}{|c|}{ July harvest } & \multicolumn{6}{|c|}{ August harvest } \\
\hline & & & \multicolumn{3}{|c|}{ Elongating } & \multicolumn{3}{|c|}{ Reproductive } & \multicolumn{3}{|c|}{ Elongating } & \multicolumn{3}{|c|}{ Reproductive } \\
\hline & Blade & Sheath & Blade & Sheath & Stem & Blade & Sheath & Stem & Blade & Sheath & Stem & Blade & Sheath & Stem \\
\hline $\begin{array}{l}\text { Ames, IA } \\
\text { Mead, NE } \\
\text { LSD (0.05) }\end{array}$ & $\begin{array}{l}0.066 \\
0.056 \\
0.004\end{array}$ & $\begin{array}{l}0.073 \\
0.059 \\
0.003\end{array}$ & $\begin{array}{l}\mathbf{0 . 0 4 5} \\
\mathbf{0 . 0 3 8} \\
\mathbf{0 . 0 0 1}\end{array}$ & $\begin{array}{l}0.043 \\
0.048 \\
0.003\end{array}$ & $\begin{array}{l}0.053 \\
0.065 \\
0.003\end{array}$ & $\begin{array}{l}0.044 \\
0.035 \\
0.002\end{array}$ & & $\begin{array}{l}0.051 \\
0.065 \\
0.004\end{array}$ & & $\begin{array}{l}0.034 \\
0.026 \\
0.002\end{array}$ & $\begin{array}{l}0.050 \\
0.041 \\
0.006\end{array}$ & $\begin{array}{l}0.044 \\
0.044 \\
0.002\end{array}$ & $\begin{array}{l}0.032 \\
0.022 \\
0.002\end{array}$ & $\begin{array}{l}0.045 \\
0.035 \\
0.004\end{array}$ \\
\hline \multicolumn{15}{|l|}{ Population, across location } \\
\hline $\begin{array}{l}\text { Trailblazer } \\
\text { Pathfinder } \\
\text { Cave-in-Rock } \\
\text { Ey } \times \text { FFLDMDC1 } \\
\text { Ey } \times \text { FFHDMDC3 } \\
\text { Pathfinder HYDMDC2 } \\
\text { LSD (0.05) }\end{array}$ & $\begin{array}{l}0.059 \\
0.058 \\
0.071 \\
0.058 \\
0.063 \\
0.057 \\
0.007\end{array}$ & $\begin{array}{l}0.066 \\
0.062 \\
0.078 \\
0.063 \\
0.064 \\
0.062 \\
0.006\end{array}$ & $\begin{array}{l}0.041 \\
0.041 \\
0.047 \\
\mathbf{0 . 0 3 9} \\
\mathbf{0 . 0 4 1} \\
\mathbf{0 . 0 3 9} \\
\mathbf{0 . 0 0 2}\end{array}$ & $\begin{array}{l}0.045 \\
0.042 \\
0.052 \\
0.040 \\
0.051 \\
0.042 \\
0.005\end{array}$ & $\begin{array}{l}0.062 \\
0.056 \\
0.066 \\
\mathbf{0 . 0 5 9} \\
\mathbf{0 . 0 5 8} \\
\mathbf{0 . 0 5 7} \\
\mathbf{0 . 0 0 5}\end{array}$ & $\begin{array}{l}0.036 \\
0.042 \\
0.041 \\
0.039 \\
0.040 \\
0.040 \\
0.003\end{array}$ & $\begin{array}{l}0.040 \\
0.038 \\
0.046 \\
0.037 \\
0.041 \\
0.038 \\
0.005\end{array}$ & $\begin{array}{l}0.057 \\
0.057 \\
0.060 \\
0.055 \\
0.061 \\
0.058 \\
0.008\end{array}$ & $\begin{array}{l}0.041 \\
0.041 \\
0.038 \\
0.044 \\
0.047 \\
0.043 \\
0.003\end{array}$ & $\begin{array}{l}0.027 \\
0.027 \\
0.041 \\
0.025 \\
0.032 \\
0.028 \\
0.003\end{array}$ & $\begin{array}{l}0.050 \\
0.049 \\
0.044 \\
0.044 \\
0.051 \\
0.035 \\
0.011\end{array}$ & $\begin{array}{l}0.044 \\
\mathbf{0 . 0 4 6} \\
\mathbf{0 . 0 4 4} \\
\mathbf{0 . 0 4 4} \\
\mathbf{0 . 0 4 7} \\
\mathbf{0 . 0 3 9} \\
\mathbf{0 . 0 0 2}\end{array}$ & $\begin{array}{l}0.024 \\
0.026 \\
0.034 \\
0.025 \\
0.027 \\
0.026 \\
0.003\end{array}$ & $\begin{array}{l}0.043 \\
0.044 \\
0.033 \\
0.044 \\
0.044 \\
0.034 \\
0.007\end{array}$ \\
\hline
\end{tabular}

TD of all populations demonstrates that any of these populations could be grazed at a vegetative stage of maturity and support high animal gains. Hay would not normally be harvested at this early stage of development because of low DM yield.

The increased digestibility reported by Hopkins et al. (1995) for Trailblazer compared with Ey $\times$ FF Low IVDMD Cycle 1 was likely due to higher $C_{D}$ in the leaf blade and stem fraction of both elongating and reproductive tillers. The increased digestibility following two additional cycles of recurrent restricted phenotypic selection for increased IVDMD in Ey $\times$ FF High IVDMD Cycle 3 was the result of both increased $C_{D}$ and $C_{S}$ in the leaf sheaths and stems of elongating and reproductive tillers and was directly related to increased extent of fiber digestion (Table 6). However, this contradicts the results of Moore et al. (1993) who concluded that only $C_{D}$ concentration increased. Even though the previously noted increase in IVDMD for Ey $\times$ FF High IVDMD Cycle 3 should result in increased average daily gains, the lower forage yield reported by Hopkins et al. (1995) and Redfearn et al. (1997) may not result in additional improvements in animal production per unit area.

During this study, all populations at Mead except Cave-in-Rock were infected by a leaf rust (presumably caused by a Puccinia species) between the elongating and reproductive maturity harvests. Foliar diseases have decreased forage quality of orchardgrass (Dactylis glomerata L.) (Edwards et al., 1981) and intermediate wheatgrass [Thinopyron intermedium (Host) Barkw. \& D.R. Dewey] (Karn et al., 1989). Forage quality of leaf blades would be expected to decline less than that of leaf sheaths or stems over time. The dramatic decrease in $C_{D}$ concentration of the leaf blade in Ey $\times$ FF High IVDMD Cycle 3 population between elongating and reproductive stages suggests that the foliar disease adversely affected $C_{D}$ and may have caused the lower observed extent of fiber digestion for these sward components (Table 6). Two mechanisms that may explain how this disease reduced the extent of fiber digestion were toxicity to fiber-degrading bacteria or inhibition of fibrolytic enzymatic activity.

Forage cultivars can be designed for specific uses and specific management practices by selecting and developing them under accepted management practices in multiple environments. Forage cultivars may fit either grazing or hay production best. At elongating or reproductive stages of maturity, those populations with increased leaf blade TD would be more suitable for grazing because of the ability of cattle to preferentially select leaf blades, whereas those populations with increased stem TD may be more appropriately harvested for hay.

The higher leaf blade and stem TD in Trailblazer across several stages of maturity make it suitable for grazing and haying. Alternatively, the increased vegeta-

Table 6. Extent of fiber digestion of leaf blade, leaf sheath, and stem components of elongating and reproductive tillers within elongating and reproductive swards of six switchgrass populations from Ames, IA, and Mead, NE, harvested during 1993.

\begin{tabular}{|c|c|c|c|c|c|c|c|c|c|c|c|c|}
\hline \multirow[b]{3}{*}{ Location, across population } & \multicolumn{6}{|c|}{ July harvest } & \multicolumn{6}{|c|}{ August harvest } \\
\hline & \multicolumn{3}{|c|}{ Elongating } & \multicolumn{3}{|c|}{ Reproductive } & \multicolumn{3}{|c|}{ Elongating } & \multicolumn{3}{|c|}{ Reproductive } \\
\hline & Blade & Sheath & Stem & Blade & Sheath & Stem & Blade & Sheath & Stem & Blade & Sheath & Stem \\
\hline & & & & & & $-\mathbf{g}$ & & & & & & \\
\hline Ames & 562 & 543 & 407 & 530 & 523 & 383 & 407 & 372 & 224 & 469 & 377 & 197 \\
\hline Mead & 547 & 487 & 368 & 551 & 516 & 284 & 353 & 409 & 270 & 335 & 417 & 199 \\
\hline LSD (0.05) & NS & 24 & 16 & 14 & NS & 29 & 15 & 14 & 15 & 21 & 13 & NS \\
\hline \multicolumn{13}{|l|}{ Population, across location } \\
\hline Trailblazer & 559 & 513 & 414 & 466 & 527 & 379 & 460 & 394 & 244 & 444 & 415 & 208 \\
\hline Pathfinder & 551 & 511 & 361 & 560 & 511 & 306 & 339 & 383 & 250 & 427 & 369 & 188 \\
\hline Cave-in-Rock & 549 & 521 & 383 & 539 & 501 & 309 & 398 & 390 & 218 & 455 & 384 & 162 \\
\hline Ey $\times$ FFLDMDC1 & 532 & 503 & 368 & 545 & $\mathbf{5 0 0}$ & 315 & 372 & 373 & 214 & 347 & 372 & 174 \\
\hline Ey $\times$ FFHDMDC3 & 574 & 503 & 414 & 575 & 537 & 330 & 340 & 412 & 307 & 351 & 433 & 252 \\
\hline Pathfinder HYDMDC2 & 563 & 541 & 387 & 557 & 541 & 361 & 373 & 391 & 250 & 389 & 407 & 204 \\
\hline LSD (0.05) & NS & NS & 27 & 21 & NS & NS & 26 & 24 & 27 & 36 & 24 & 21 \\
\hline
\end{tabular}


tive leaf blade TD of Ey $\times$ FF High IVDMD Cycle 3 makes it the most attractive for grazing; however, the decreased leaf blade TD of elongating and reproductive tillers at later sward maturities would limit its value for late-season grazing. Because it still had the greatest TD at a reproductive stage of maturity because of increased $C_{D}$ and $C_{S}$ in the leaf sheaths and stems, it could be harvested as a hay crop. An effective management strategy may be to graze this population prior to elongating sward maturity, then harvest a cutting of hay later in the growing season.

Management of switchgrass for grazing or hay production should be based on the TD of the sward components. Although these populations are adapted to the midwestern USA and TD was relatively stable across locations, TD of the individual morphological components was not stable throughout the growing season. Likewise, the importance of forage quality evaluations for switchgrass at several different morphological stages is apparent.

The high genetic correlations to digestibility exhibited in smooth bromegrass (Bromus inermis Leyss.) led Reich and Casler (1985) to suggest that selection for forage quality could be efficiently conducted at vegetative stages. This may not be a reliable selection technique for switchgrass as significant differences in leaf sheath and stem digestibility may be overlooked at later maturities. Because of complex $\mathrm{G} \times \mathrm{E}$ interactions for TD in sward components, results from this study and those of Hopkins et al. (1995) indicate that improvements in fiber digestion of switchgrass may be valid only for the growth stage at which the plants were selected. Furthermore, the previously observed differences in whole-plant forage digestibility of these same populations were probably due to genetic differences among sward components for fiber digestibility.

\section{REFERENCES}

Allen, M.S., and D.R. Mertens. 1988. Evaluating constraints on fiber digestion by rumen microbes. J. Nutr. 118:261-270.

Anderson, B., J.K. Ward, K.P. Vogel, M.G. Ward, H.J. Gorz, and F.A. Haskins. 1988. Forage quality and performance of yearlings grazing switchgrass strains selected for differing digestibility. J. Anim. Sci. 66:2239-2244.

Edwards, M.T., D.A. Sleper, and W.Q. Loegering. 1981. Histology of healthy and diseased orchardgrass leaves subjected to digestion in rumen fluid. Crop Sci. 21:341-343.

Fritz, J.O., K.J. Moore, and K.P. Vogel. 1991. Ammonia-labile bonds in high- and low-digestibility strains of switchgrass. Crop Sci. 31: 1566-1570.
Goering, H.K., and P.J. Van Soest. 1970. Forage fiber analysis (apparatus, reagents, procedures, and some applications). USDA-ARS Handbook No. 379. U.S. Gov. Print. Office, Washington, DC.

Hopkins, A.A., K.P. Vogel, and K.J. Moore. 1993. Predicted and realized gains from selection for in vitro dry matter digestibility and forage yield in switchgrass. Crop Sci. 33:253-258.

Hopkins, A.A., K.P. Vogel, K.J. Moore, K.D. Johnson, and I.T. Carlson. 1995. Genotype effects and genotype by environment interactions for traits of elite switchgrass populations. Crop Sci. 35 $125-132$

Karn, J.F., J.M. Krupinsky, and J.D. Berdahl. 1989. Nutritive quality of foliar disease resistant and susceptible strains of intermediate wheatgrass. Crop Sci. 29:436-439.

Marten, G.C., and R.F Barnes. 1980. Prediction of energy digestibility of forages with in vitro rumen fermentation and fungal enzymes p. 61-71. In W.J. Pigden et al. (ed.) Standardization of analytical methodology of feeds. 12-14 March 1979. Int. Dev. Res. Ctr., Ot tawa, Canada.

McIntosh, M.S. 1983. Analysis of combined experiments. Agron. J. 75:153-155.

Mitchell, R.B., K.J. Moore, L.E. Moser, and J.O. Fritz, and D.D. Redfearn. 1997. Predicting developmental morphology in switchgrass and big bluestem. Agron. J. 89:827-832.

Moore, K.J., and J.H. Cherney. 1986. Digestion kinetics of sequentially extracted cell wall components of forages. Crop Sci. 26:1230-1235.

Moore, K.J., L.E. Moser, K.P. Vogel, S.S. Waller, B.E. Johnson, and J.F. Pedersen. 1991. Describing and quantifying growth stages of perennial forage grasses. Agron. J. 83:1073-1077.

Moore, K.J., K.P. Vogel, A.A. Hopkins, J.F. Pedersen, and L.E. Moser. 1993. Improving the digestibility of warm-season perennial grasses. p. 447-448. In Proc. Int. Grassl. Congr., 17th, Palmerston North, NZ. 8-21 Feb. 1993. New Zealand Grassl. Assoc., Palmerston North.

Nelson, C.J., and L.E. Moser. 1994. Plant factors affecting forage quality. p. 115-154. In G.C. Fahey, Jr., et al. (ed.) Forage quality, evaluation, and utilization.ASA, CSSA, and SSSA, Madison, WI.

Newell, L.C. 1968. Registration of Pathfinder switchgrass. Crop Sci. 8:516.

Redfearn, D.D., K.J. Moore, K.P. Vogel, S.S. Waller, and R.B. Mitchell. 1997. Canopy architecture and morphology of switchgrass populations differing in forage yield. Agron. J. 89:262-269.

Reich, J.M., and M.D. Casler. 1985. Genetic variation for response to advancing maturity of smooth bromegrass forage quality traits. Crop Sci. 25:641-646.

Robertson, J.B., and P.J. Van Soest. 1977. Dietary fiber estimation in concentrate feedstuffs. J. Anim. Sci. 45 (Suppl. 1):254.

SAS Institute, Inc. 1985. SAS User's guide: Statistics. 5th ed. SAS Inst., Inc., Cary, NC.

Twidwell, E.K., K.D. Johnson, J.H. Cherney, and J.J. Volenec. 1988. Forage quality and digestion kinetics of switchgrass herbage and morphological components. Crop Sci. 28:778-782.

Van Soest, P.J. 1982. Nutritional ecology of the ruminant. O\&B Books, Inc. Corvallis, OR.

Vogel, K.P., F.A. Haskins, and H.J. Gorz. 1981. Divergent selection for in vitro dry matter digestibility in switchgrass. Crop Sci. 21:39-41.

Vogel, K.P., F.A. Haskins, H.J. Gorz, B.E. Anderson, and J.K. Ward. 1991. Registration of 'Trailblazer' switchgrass. Crop Sci. 31:1388.

Waldo, D.R., and L.W. Smith. 1972. Model of cellulose disappearance from the rumen. J. Dairy Sci. 55:125-129. 